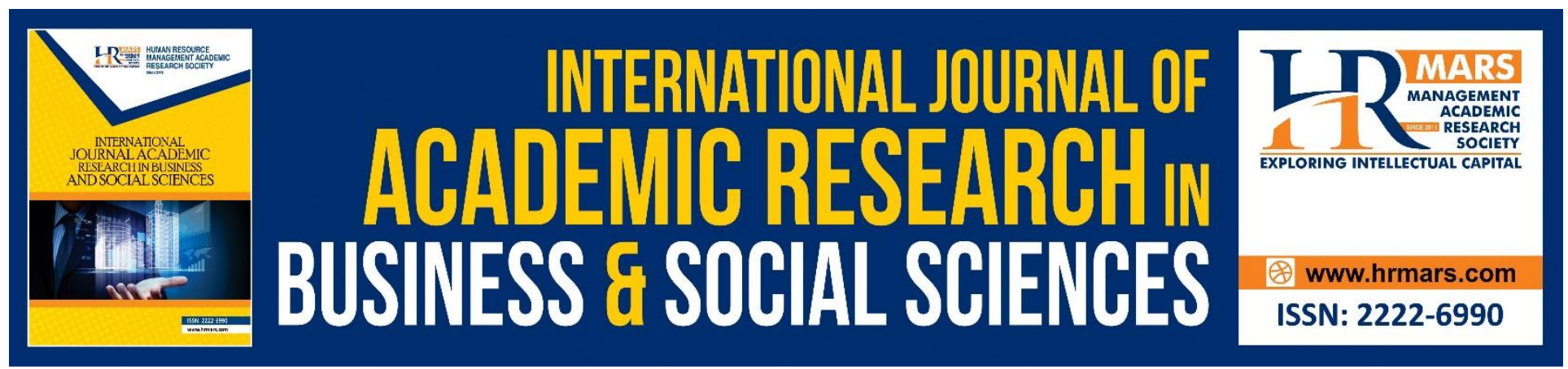

\title{
The Level of Knowledge of Academicians Concerning the Whereabouts of Allah: A Case Study
}

\author{
Mohd Nizam Sahad, Fathullah Asni
}

To Link this Article: http://dx.doi.org/10.6007/IJARBSS/v10-i7/7399

DOI:10.6007/IJARBSS/v10-i7/7399

Received: 02 April 2020, Revised: 06 May 2020, Accepted: 16 June 2020

Published Online: 24 July 2020

In-Text Citation: (Sahad \& Asni, 2020)

To Cite this Article: Sahad, M. N., \& Asni, F. (2020). The Level of Knowledge of Academicians Concerning the Whereabouts of Allah: A Case Study. International Journal of Academic Research in Business and Social Sciences, 10(7), 103-115.

Copyright: (C) 2020 The Author(s)

Published by Human Resource Management Academic Research Society (www.hrmars.com)

This article is published under the Creative Commons Attribution (CC BY 4.0) license. Anyone may reproduce, distribute, translate and create derivative works of this article (for both commercial and non-commercial purposes), subject to full attribution to the original publication and authors. The full terms of this license may be seen at: $\underline{\text { http://creativecommons.org/licences/by/4.0/legalcode }}$

Vol. 10, No. 7, 2020, Pg. 103 - 115

Full Terms \& Conditions of access and use can be found at http://hrmars.com/index.php/pages/detail/publication-ethics 


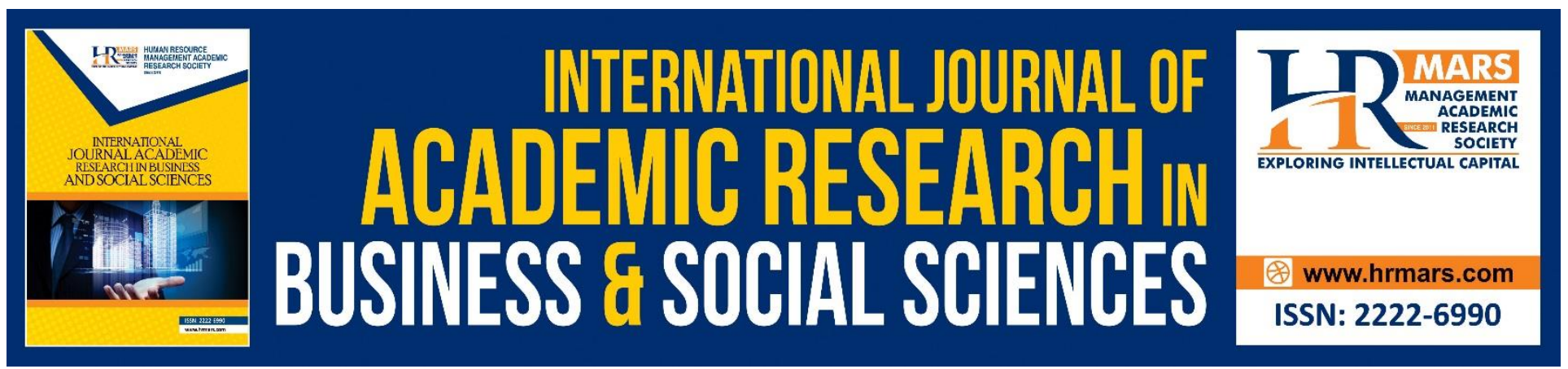

\title{
The Level of Knowledge of Academicians Concerning the Whereabouts of Allah: A Case Study
}

\author{
Mohd Nizam Sahad \\ School of Humanities, Universiti Sains Malaysia. Penang, Malaysia \\ nizamsahad@usm.my \\ Fathullah Asni \\ Faculty of Islamic Studies, Kolej Universiti Islam Perlis. Perlis, Malaysia \\ Email: fathullah@kuips.edu.my
}

\begin{abstract}
The purpose of this study is to assess the knowledge of selected lecturers, in one of the faculties of a local university, regarding the whereabouts of Allah SWT. This qualitative study was conducted based on the debates made by Islamic clerics and scholars in the field of aqidah, and a total of 14 lecturers were selected randomly and interviewed. The study found that the informants' understanding and knowledge concerning the dalil about Allah's whereabouts were relatively inadequate, as only one of the informants could aptly answer the questions given, even though the informant was unable to explain the phenomenon in terms of dalil naqli. The remaining 13 informants did not know about the dalil of revelation. Consequently, the researchers suggested that an aqidah study through the approach of Salaf should be instilled among the lecturers to improve their knowledge of Allah and give them a more concrete understanding of Him based on the foundation of the revelation.
\end{abstract}

Keywords: Academic members, where is Allah, Salaf and Khalaf, Asya'irah, Mu'tazilah.

\section{Introduction}

'Awwaluddin Ma'rifatullah' is a well-accepted term used to refer to the basics of religion, which means "the foundation of religion is to know Allah" (Ismail, 1998). The love of a servant for his or her Creator will develop upon knowing Allah, the creator. It is also compulsory to be acquainted with Allah SWT based on the knowledge of revelation disclosed to Prophet (PBUH) (Salleh et al., 2017). Firdaus (2012) stressed that the installation of the knowledge about knowing Allah SWT should begin in the early stages of childhood. However, in reality, knowledge related to matters of aqidah (creed) seem to be neglected by society. As a consequence, the breakdown of aqidah becomes a threat to the well-being of individuals, society, and country (Salleh et al., 2013). The knowledge of the aqidah can be defined as the knowledge of Allah SWT and its attributes according to the reference of the Quran and al-hadith and convinced it. 
INTERNATIONAL JOURNAL OF ACADEMIC RESEARCH IN BUSINESS AND SOCIAL SCIENCES Vol. 10, No. 7, July, 2020, E-ISSN: 2222-6990 @ 2020 HRMARS

There are various debates and questions concerning matters attached being knowledgeable about Allah, leading to further questions which may be deemed as simple, but somehow leaves many unable to provide the answer. One of these questions being focused on in this study was, "Where is Allah?' Previous studies by Sahad's (2007) and Alwi's (2007a) discovered that the knowledge about aqidah among Muslims in Malaysia is considerably shallow. According to Sahad (2007), many Muslims in Malaysia solely practice the concept of taqlid (conformity of one person to the teaching of another) in their understanding of their aqidah. This would undoubtedly lead to the exposure of the influence of bidaah (heresy) and hereditary heresies (Alwi, 2007b; Ibrahim et al., 2013). A literature review was conducted on this issue, and it is apparent in the previous studies that the whereabouts of Allah is widely debated in the social media in the form of opinion polls in blogs, Facebook, and other websites, which is somewhat descriptive.

Many previous studies have investigated a study by Stewart (2016) which was conducted in China to examine the debate about the sectarian view of aqidah according to the Salafis (followers of an Islamic movement), particularly regarding the issue of the whereabouts of Allah. Baadel (2015) conducted a survey among Z-generation youths in the Canadian University of Dubai through which he discovered that the majority of Muslim youths in the United Arab Emirates were uncertain of the whereabouts of Allah. This suggests that the religious subjects offered the university should be reevaluated.

Besides, two books written by Patel (2013) and Apple (2016) concerning this issue were also reviewed. Patel's (2013) book was descriptive; he attempted to prove the grandeur of Allah instead of a critical analysis of the issue about the whereabouts of Allah. Meanwhile, Apple's (2016) book was a light reading based on Islamic sources and scientific evidence to enable children to comprehend questions about aqidah according to their intellectual age.

The discussion above indicates that it is a research gap concerning Muslim people's knowledge about the whereabouts of Allah that had not been answered by previous research. This study aims to examine the level of understanding of the matter with a specific focus on academicians' level of knowledge. This is achieved using a qualitative approach, which is in contrast to Baadel's (2015) quantitative study which focused on students. Before the actual study was conducted, initial themes of possible answers had been constructed based on several extended interviews with members of the public. The themes are listed below.

1. Where is Allah?

a) Fi's-samaa (in the sky)

b) Fi Kulli Makan (anywhere)

c) Fi al-'Arasy (at His throne)

d) Fi al-Insan (in human beings)

e) Allah Mawjud Bila Makan (Allah's existence has no particular location)

Based on this initial construct, the study proceeded to the actual study. The study aims to assess the level of knowledge of academicians about the whereabouts of Allah. The academicians who were selected as the respondents of the study came from diverse areas of specialization. They were asked fundamental questions about divine aqidah to observe their ability to present related dalil (analogical reasoning) on the questions asked. The academicians were selected randomly as a sample since the nature of their career is rooted in knowledge. The results of the study will illustrate the academicians' level of understanding of the questions that were asked. The initial hypothesis predicts that this 
INTERNATIONAL JOURNAL OF ACADEMIC RESEARCH IN BUSINESS AND SOCIAL SCIENCES

Vol. 10, No. 7, July, 2020, E-ISSN: 2222-6990 @ 2020 HRMARS

fundamental question is also unattended by the academicians, as Baadel's (2015) discovery in his study of students.

\section{The Concept of Allah SWT Whereabouts}

All of the aforementioned answers to the question of where Allah SWT are fundamentally based on the teachings of Islam. One would argue that the answers are also influenced by the perspective of just particular groups of believers, some of which are inaccurate. There are several schools of thoughts on aqidah, including the Salaf and Khalaf viewpoints, which subsequently resulted in different responses to the question of Allah's whereabouts, Salaf is defined from the aspect of time (zamani) and method (manhaji) (Haron et al., 2013). Salaf zamani consists of Muslims who lived 200 years after the time of the Prophet Muhammad (PBUH), whilst Salaf manhaji refers to Muslims who follow the Salaf method which implies that they will not interpret the verses of mutasyabihat (verses of al-Qur'an with layered or vague meaning) even if they live in the present time. This school of thought claims that Allah sits on His Throne without 'questioning how' or 'without how' (bilaa kayf) (Haron, 2008). In other words, they accept the answers to the theological questions about Islam without doubting or questioning. There are also claims that the Salaf zamani are the threegenerations of the Companions of the Messenger of Allah, tabi' and tabi'in (the generation after the Muslims followers who were born after the passing of the Prophet but who were contemporaries of the Companions) as stated in the hadith of the Prophet which means "the best people are those of my generation, and then those who will come after them (the next generation), and then those who will come after them (i.e. the next generation), and then after them, there will come people whose witness will precede their oaths, and whose oaths will precede their witness." (al-Bukhari 1422H). ${ }^{1}$ According to Rabi'ah and Malik, "the setting is known, the how is unknown, belief in it is obligatory, and asking about the how of it is an innovation, for asking what is unknown to humans and impossible to be answered except through the source of revelation" (Ibn Taimiyyah, 2000).

Some information regarding the substance and nature of Allah is known based on what has been mentioned in the Qur'an and the hadith. Nevertheless, Allah decrees that "there is nothing whatever like unto Him, and He is the One that hears and sees (all things)." (Q 42:11). The substance of Allah, His attributes, His names, and His actions cannot be compared to anything except in reference of the name, when in fact Allah has a substance that is not similar or equal to the substance of any beings. The substance is attributed to the characteristics that do not resemble any of the attributes of the beings (Ibn Taimiyyah, 2000).

The followers of Khalaf; otherwise known as kalaam (theological rhetoric) are Muslims in the later periods after the $3^{\text {rd }}$ Salaf period of Hijrah, where the takwil (explanation) method was introduced (Haron, 2008; al-Laqqani, 2004). This method is steeped with philosophical and mantic methodologies from a series of translations of foreign works primarily from Greek into Arabic. The translations had a profound impact on some of the Islamic clerics' thinking methods at the time and further encouraged the development of kalaam knowledge (Sahad, 2007).

The change of thoughts from Salaf to Khalaf was also due to Islamic rulers, forcing many of the Islamic clerics who defended the Salaf method to abide by the government's will and those who defied were tortured and imprisoned (Ibn Kathir, 1997). One example of the clash of thoughts is that Allah sits above the Throne but explained it as istawla (conquering and having dominion over). It is merely a symbolic explanation that a king has a throne that governs his land. Thus, he ascends the throne ('arasy) because a king does not sit static on his throne (al-Laqqani, 2004). 
INTERNATIONAL JOURNAL OF ACADEMIC RESEARCH IN BUSINESS AND SOCIAL SCIENCES Vol. 10, No. 7, July, 2020, E-ISSN: 2222-6990 @ 2020 HRMARS

The method used by kalaam followers differs from the Salaf-Salafiyyah's. Kalaam members believe in Allah and accept all teachings of the Prophet SAW, but they incline to reinforce their belief with mentally logic dalil. This means that they have left the concept of faith that is based on fitra (primordial nature) held by the Salaf-Salafiyyah, instead of using the method of mental reasoning (Abu Zahrah, 1996). Adherers to this sect consider the method of al-Qur'an dalil on the existence of Allah to be very simple and easy, as mentioned by Allah, which implies, there is no doubt about Allah, the Creator of heaven and earth. (Q 71:16). It is insufficient for the kalaam members to explain verses of mutasyabihat solely using this verse (Wahab et al., 2014).

The kalaam members consist of two major groups, that is, Mu'tazilah and Asya'irah. However, it is important to note that the method of takwil in understanding al-Qur'an and hadith is not composed of only these two groups, but it also includes tasawwuf (Sufism) and many more sects or individuals identified using the takwil method (Haron, 2008). The Asya'irahs explain some verses of mutasyabihat, while the Mu'tazilahs explain all verses of mutasyabihat. The Mu'tazilahs are heavily influenced by Greek philosophy and are called members of the Islamic philosophers and rationalists (Hatta, 2013). Such understanding can lead to greater misunderstanding (al-Jawzi, 1403). However, the Asya'irahs are still absolved to whether they should explain or follow the Salaf way and prioritize the revelation nass (a known or clear, legal injunction). Meanwhile, the Mu'tazilahs' stand on the matter is mere takwil is sufficient, causing a strong opposition between the Asya'irah and Mu'tazilah thoughts. Consequently, the Mu'tazilah school of thought collapsed with the rise of the Asya'irah school of thought (al-Syahrastani, 1992; Wahab et al., 2013).

According to the method of Asya'irah, concerning the question of the whereabouts of Allah, is that Muslims are able to know Allah's attributes, actions, and names based on the revelation. However, they are unable to know His substance as it is unachievable by merely relying on human reason. Hence, it indirectly concludes that Allah exists without the need to be associated with any particular location (al-Syahrastani, 1992). This makes the Asya'irah's stand very close to that of the Salaf's (Wahab et al., 2013). This matter is also strongly supported by the principle of Asya'irah that prioritizes revelation in all circumstances (al-Asy'ari, 1955; al-Laqqani, 2004).

However, Ibn Kathir (1997) states that al-Asy'ari, the founder of the Asy'irah sect returned to the understanding of the ahl al-Sunah (the people of the sunnah and community) at the end of his lifetime after practised the credo of takwil after so long, positing (isbat) all the attributes of Allah without determining kaifiyyat (character, manner, way) and not equating the attributes of Allah with any created beings. Based on this, al-Asya'ri (1397H) supports Ahmad bin Hanbal's ideology of believing that Allah is at His high Throne which is perfectly deserving of Him. Al-Asya'ri adapted this knowledge from Zakariyya al-Saji, a student of Ahmad bin Hanbal (al-Zahabi, 1995). According to alAsy'ari (1397H), Allah is eminent and resided above (istiwa $\left.a^{\prime}\right)$, on His Throne, as Allah SWT says, which means, "(God) Most Gracious is firmly established on the throne (of authority)." (Q 20:5) This claim proves that al-Asy'ari did not distort the meaning for terms such as to Istawla or Qahara, which have the meaning of authority as defined by the Asya'irah. Some of them declare Allah to be anywhere while some declare that Allah exists without being at any particular location. These declarations stem from the Mu'tazilah's aqidah which al-Asy'ari had escaped from. According to al-Asy'ari (1413H), it is mutually agreed among the Islamic clerics that Allah is high above His Throne. Al-Asy'ari (1990) opposes the declarations that Allah is anywhere or Allah exists without any particular location since it is a Mu'tazilah's ideology. However, many Asya'irahs adapted al-Asy'ari's views before he retracted his views to follow the Salaf sect. 
INTERNATIONAL JOURNAL OF ACADEMIC RESEARCH IN BUSINESS AND SOCIAL SCIENCES Vol. 10, No. 7, July, 2020, E-ISSN: 2222-6990 @ 2020 HRMARS

Meanwhile, the Mu'tazilah, otherwise known as the mu'attilah (denying the attribute of Allah) believe that the nature and substance of Allah that He is All-Knowing, All-Hearing, All-Seeing, and others are part of His substance instead of His attributes (al-Syahrastani, 1992). This is because if Allah has substance and attributes, Allah is multiplied. Thus, the Mu'tazilahs combine the substance of Allah with His attributes as the basis of their view of the One True God (Ismail, 1998). For example, Allah is All-Knowing of all things with His substance instead of His attributes. Due to this understanding, the Mu'tazilahs claim that Allah is everywhere. This understanding is strongly opposed by the Asya'irahs because they believe that if Allah is everywhere, which by that logic implies that Allah will also exist in the toilet, in a vessel of excrement, and in the stomach of Maryam (alAsya'ari, 1397H). This understanding still exists today, particularly among the Shi'a Zaidiyyah (Hatta, 2013).

There are those who claimed that Allah consolidates with human beings, thus, placing Allah within human beings. This teaching was founded by Husein Ibn Mansur al-Hallaj, who introduced the concept of hulul in his teachings. Hulul means God takes place in a certain human body, that is, human beings who were able to eliminate their human attributes through mortality (Emroni, 2009). According to al-Hallaj, God and humans have the attributes of lahut (content or secret life) and nasut (form or container) that lead to the unity between God and human in the way God enters into the human body that has lost its humanly attributes (i.e. nasut) and being replaced by divine attributes, such as al-Hallaj's statement "Ana al-Haq" (I am the Truth). This is because the One who uttered the words was not the individual himself, but God. Al-Hallaj has also said, "I am the secret of the Truth." Hulul or the incarnation of God in the human body is achieved after having gone through a variety of practices (Emroni, 2009).

The theories of lahut and nasut existed based on the concept of the first human creation, who is Prophet Adam. It is believed that God created him as an incarnation of Himself with all His attributes and greatness. According to al-Hallaj, Allah commands the Angels to prostrate to Adam as mentioned in Surah al-Baqarah [2] verse 34 since Adam's being is an incarnation of Allah, as of His incarnation in Prophet Isa (Jesus) (Kailani, 1991). Among the essence of al-Hallaj's teachings is the concept of haqiqah Muhammadiyyah (The Reality of Muhammad), which is the creation of this world is derived from nur (light) Muhammadiyyah.

In other words, according to al-Hallaj, Prophet Muhammad SAW was created from two elements, which are qadim (classical roots with no beginning and ending) light and the element of humanity (the Prophet). The light that is qadim is also taken to create all beings. Nur Muhammad is of the qadim attribute, but it is in contrast with the qadim of Allah SWT. However, the only difference is in the name alone; qadim, referring to the substance of Allah SWT is mentioned first, while the second view is that Muhammad as a human, prophet, and messenger of Allah went through death (Kailani, 1991). Thus, there are two perceptions of Muhammad, that is, the Muhammad that is seen as a man, the Prophet who is hudus (of new nature) and the essence of his creation in the form of nur of qadim and azali (eternal) attributes. His divine habits which are of the qadim attribute are called lahut, while his humanity habits which are new in nature are called nasut. These concepts of al-Hallaj's teachings are influenced by the previous Sufi teachings of Shia, Christianity, and Neo-Platonism Emanation (Emroni, 2009). Al-Hallaj's teachings have been indicted by al-Jawzi (1403H) as deviant.

Therefore, based on the question of where Allah is, this study believes that the best religious doctrine on this matter is that of the Salaf's understanding. This is because the opinion is based on an understanding of the revelation that is not influenced by the affairs of philosophical and logical 
controversies. This opinion is strong because it is supported by revelation in which Allah SWT mentions, which means, "Do you feel secure (fearless) that He Who is in Heaven... Or do you feel secure (fearless) that He Who is in Heaven..." (Q 67:16-17). In paraphrase, The Prophet SAW also says, "Don't you trust me though I am the truth worthy man of the One in the Heavens, and I receive the news of Heaven (i.e. Divine Inspiration) both in the morning and in the evening?" (al-Bukhari, 1422H) ${ }^{2}$

Likewise, this is evidenced by the testimony of a slave girl with faith when she tells that Allah is in the sky based on Mu'awiyyah bin al-Hukm al-Silmi's event where he had beaten his slave girl due to her negligence in taking care of his livestock. He then regretted it and went to the Prophet SAW in a state of regret, seeking the Prophet SAW's permission to release the slave girl. Thus, the Prophet SAW called the slave girl and asked her about the whereabouts of Allah. The slave girl said, "Allah is in the heavens." The Prophet SAW the asked, "Who am I?" The slave girl replied, "You are the Messenger of Allah." The Prophet SAW said, "Set the slave girl free because she is a believer." (Muslim, 2006) 3

Nevertheless, it should be noted that it does not mean that He nor His mass is in the sky, but that the desired meaning of 'sky' is highness and greatness (Al-Asyqar, 2004). This is because, according to linguists, istiwaa' has several meanings, and thus, the most appropriate meaning of the divine nature is the Highest (Harras et al., 2010). Furthermore, Allah has described Himself as the Highest, based on His words, which means, "Glorify the name of your Guardian-Lord Highest." (Q 87:1) and that He is the Highest, the Most Supreme, as mentioned by Allah SWT, which means, "His Throne does extend over the heavens and the earth, and He feels no fatigue in guarding and preserving them for He is the Highest, the Supreme (in glory)." (Q 2:255). Likewise, as mentioned in surah al-Nahl [16] verse 50 and al-An'am [6] verse 18.

Al-Zahabi and al-Auza'i claimed that the Companions, tabi'in, and the imams (leader), including the four imams (a title for the Allah-appointed successors of Muhammad) have all agreed that Allah SWT is high above the sky and upon His throne (al-Zahabi, 1995). Al-Khumais (1992) states that the four Imams, as narrated by Abu Hanifah said, "And Allah is called upon upwards, and not downwards, because downwards is not a quality of Rububiyyah (Lordship) and Uluhiyyah (Divinity) in anything." Abu Hanifah added, "Whoever says: I do not know whether my Lord is above the sky, or on the earth, then he has indeed disbelieved. Likewise, whoever says that He is above the throne. And I do not know whether the throne is in the sky, or the earth." Abu Hanifah points out that Allah is fi's-samaa (above the sky), not on the earth. Meanwhile, Malik said, "Allah is fi's-samaa (above the sky) and His knowledge is in every place." According to al-Shafi'i, "Allah is above His Throne, above the sky (fi'ssamaa). He draws close to His creation; however, He wishes, and that Allah the Exalted descends to the lowest heaven, however, He wishes." Ahmad said, "We believe that Allah is above His Throne However He wishes and as He wishes, without a limit (hadd), nor an Attribute that the describer can comprehend, nor a limit which the describer can place." Thus, this understanding makes the aqidah of all these imams free from the elements of tahrif (distortion), ta'til (divesting Allah), tashbih (parable), or tamthil (resemblance) (al-Khumais, 1992).

From a logical reason, the Salafis do not interpret and explain the nass relating to aqidah due to two reasons. First, they believe that such a study does not give any benefit to the Muslims and second, human reason cannot explain matters that are connected with Allah and His attributes unless when compared to themselves. Comparative work like this is a huge mistake. Hence, what is mentioned in the Quranic nass of Allah is 'to not ask how' (unquestionable). This is the attitude shown 
by the Salaf or Salafiyyah of Islam since the time of the Prophet SAW until the Abbasid era and in later times (Haron, 2008).

Also, according to al-Qaradawi (2006), it is sensible to emphasize the Salaf approach due to several factors. Namely, the limitation of human intellect and reasoning, takwil is not free from mistakes. Takwil could lead to the alteration of the meanings of the Qur'an. Instead, the Salaf s mutual consensus agreed that it is safer and being committed to matters which are agreed upon is more important than being committed to matters which are still debated. Most of the big figures of manhaj (the methodology by which truth is reached) takwil had retracted their statements. Besides that, by avoiding the takwil method in the verses of mutasyabihat, one can also avoid from committing the mistakes of misinterpreting the verses of Allah, as the Jews did, whereby based on historical facts they were involved in altering and distorting the verses of God based on their desires (Ibn Kathir, 1997). Therefore, it can be concluded that Allah SWT is high above His Throne in the sky without human beings knowing anything of its condition. This statement is based on the guidance of the Qur'an, and the hadith and everything beyond that is unknown.

\section{Methodology}

This study was carried out by combining method through literature research, data collection and a field study. A literature study was conducted to highlight works related to the question of the whereabouts of Allah. Meanwhile, the field research was conducted through an unstructured interview to find out about academicians' knowledge regarding the question and their knowledge about the dalil to support their answers. In the first step of the study, a literature study was conducted to highlight the views of the Salaf and Khalaf ulema (clerics) on the whereabouts of Allah SWT.

The second step involves the process of questioning the selected Muslim academicians using a purposive sampling method. Sampling is a systematic procedure for the selection of a group to be used as a study (Jasmi, 2012). The sampling method is meant for the researchers to identify a sample to obtain the data and information required in answering the question (Yahaya et al., 2007). The sample of this study consists of 14 lecturers in one of the faculties of a local university. Among the factors of the selection of this population is based on Creswell's (2008) suggestion that researchers should choose appropriate and easy-to-approach participants and a place of study to get accurate study results (Mohamed et al., 2016). Besides that, this population was chosen because the academics are Muslims and are people whose career paths are rooted in knowledge. Hence, as Muslim academicians' knowledge of fardhu ain (knowledge which must be studied and practiced by every Muslims) should be given priority relative to other fields of knowledge. The sample size of this study is limited to 14 informants because the number has reached the saturation of findings. The sample size for this study is achieved through the continued support of the measurement or criteria of theoretical saturation. According to Glaser and Strauss (1967) and Lincoln and Guba (1985), theoretical saturation takes place or occurs when no new themes or categories appear and there is no relevant data that can discuss or act on the existing categories.

Qualitative data concerning the question of 'where is Allah' is presented based on the themes of the question raised. There are four questions submitted to the informants that can be themed, which are as follows:

1) The importance of knowing Allah

2) The question of where Allah is. 
INTERNATIONAL JOURNAL OF ACADEMIC RESEARCH IN BUSINESS AND SOCIAL SCIENCES Vol. 10, No. 7, July, 2020, E-ISSN: 2222-6990 @ 2020 HRMARS

3) Dalil on where Allah is.

4) Suggestions on how people know more about the question of where Allah is.

Fourteen lecturers with various specialised backgrounds were interviewed, from which two were from the English, Literary, Historical, Islamic Studies, Translation, Malay, and Geography fields. The interviews were held for $\mathbf{2 0}$ minutes on average for each informant. The data obtained through the interview process were analysed to obtain a more detailed study result.

\section{Results and Discussions}

The results on the question of 'awwaluddin ma'rifatullah' showed that all the informants acknowledge that as Muslims, it is their responsibility to know Allah SWT. These findings reveal that the informants were aware of and agreed on the importance of the knowledge of aqidah, particularly in knowing Allah SWT.

Table 1

\begin{tabular}{|l|l|l|}
\hline Where is Allah? & $\begin{array}{l}\text { No. } \\
\text { Informants } \\
(\mathbf{N = 1 4 )}\end{array}$ & $\begin{array}{l}\text { Percentage } \\
\text { (\%) }\end{array}$ \\
\hline Allah exists anywhere & 8 & 57 \\
\hline Allah exists in human beings & 2 & 14 \\
\hline $\begin{array}{l}\text { Allah exists without any particular } \\
\text { location }\end{array}$ & 3 & 21 \\
\hline Allah exists in the sky & 1 & 7 \\
\hline
\end{tabular}

On the question of where Allah is, the informants have given different answers, as listed in Table 1 above. A total of eight informants answering that Allah exists anywhere, whereas two informants answer that Allah exists in the human being, three informants answered that Allah exists without being restricted to any particular location, and one informant answers that Allah exists in the sky. The answer to 'Allah exists anywhere' is represented by 57 per cent of informants. For instance, one informant mentions that "Allah is everywhere, in various places", while another informant mentions that "Allah is all around us." This answer is similar to the Mu'tazilah's credo, where they believe that attributes and substance are one and similar, likewise Allah knows everything no matter where they are. Thus, this means that Allah exists anywhere, including in the toilet and the vessel of excrement. However, this statement has been denied by Abu Hasan al-Asya'ari (1397H), whereby he claims that if Allah is anywhere, Allah is also a despicable place. Hence, the true statement, as claimed by Imam Malik is that "Allah is in the sky, and His knowledge is in every place" (al-Khumais, 1992).

Fourteen per cent of the informants' answer 'Allah exists in human beings'. One of the informants mentioned that "Allah exists in our soul, in our hearts that we could feel Him". This answer is indirectly similar to al-Hallaj's teachings, whereby in his teachings, he claims that Allah manifests in human beings. This belief is inaccurate and has been indicted by al-Jawzi $(1403 \mathrm{H})$ as deviant. Three informants (21\%) answer that 'Allah exists without being restricted to any particular location'. This answer is rather weak because Allah SWT does not deny His location, whereby in the Qur'an and hadith, it is mentioned that Allah exists above the Throne. This answer also violates the Salaf s agreement that Allah SWT is above the sky and His Throne, as stated by al-Zahabi and al-Auza'i (al- 
INTERNATIONAL JOURNAL OF ACADEMIC RESEARCH IN BUSINESS AND SOCIAL SCIENCES Vol. 10, No. 7, July, 2020, E-ISSN: 2222-6990 @ 2020 HRMARS

Zahabi, 1995). Meanwhile, only one informant (7\%) answers that 'Allah exists in the sky', whereby the informant claims that "Allah exists in the sky where He deserves to be. This is an accurate statement as shown by the Qur'an and ahadith, Salaf consensus, and the i'tiqaad (followeth, principles of guidance) of the four imams since it is free from the element of tahrif, ta'til, tashbih, or tamthil (al-Khumais, 1992). Based on the findings of this study, it can be concluded that the informants' knowledge of the existence of Allah or the whereabouts of Allah is shallow, which is consistent with Baadel's (2015) findings in his study.

Table 2

\begin{tabular}{|l|c|c|}
\hline \multicolumn{1}{|c|}{ Knowledge on Dalil } & No. of Informants & Percentage (\%) \\
\hline Know revelation dalil & 1 & 7 \\
\hline $\begin{array}{l}\text { Don't know revelation } \\
\text { dalil }\end{array}$ & 13 & 93 \\
\hline Know logical dalil & 6 & 43 \\
\hline Don't know logical dalil & 8 & 57 \\
\hline
\end{tabular}

Further questions were designed to identify the informants' knowledge on the dalil concerning the whereabouts of Allah - whether they are of the revelation dalil or logical dalil. Only one informant (7\%) is able to present a revelation dalil, while the other $13(93 \%)$ are unable to. One informant presented a dalil based on the verses of al-Qur'an, which means, "There is nothing whatever like unto $\mathrm{Him}$, and $\mathrm{He}$ is the One that hears and sees (all things)." (Q 42:11) and "And there is none like unto Him." (Q 112:4). These two verses of the Qur'an are presented by the informant in order to support his statement that 'Allah exists without being restricted to any particular location'. However, this dalil is not solid enough to be a backbone to the statement because there are many other Qur'anic verses which indicate where Allah is, and Allah SWT also does not deny His location. A majority of the informants are unable to read the dalil naqli (a reference to those sciences that can be learned only through transmission, going back ultimately to the founder of the science in question, and, in the case of the religious sciences, to the Revelation itself) in detail. The results of this study support the findings and views of Sahad's (2007) and Alwi's (2007a) study that the knowledge of aqidah among Muslims in Malaysia is still shallow.

A total of six informants (43\%) offer a logical dalil, while the remaining eight informants (57\%) fail to do so. The first informant who presents a logical dalil claims that Allah administers the universe, and thus, Allah is anywhere. The second informant claims that the existence of Allah is beyond the capability of the human minds, but analogies can be made, such as milk contains calcium which cannot be seen. The third informant states his logical dalil that Allah exists in human beings because humans can feel the presence of God in themselves even though they are unable to see Him. The fourth informant gives his logical dalil that Allah certainly does not want to be in a place since place and time are His creations. This logical dalil is presented to support his statement that Allah exists without being linked to any particular location. The fifth informant states that humans can die anywhere, what more Allah knows all of the humans' actions and deeds. This is also to support his statement that Allah exists anywhere. The sixth informant presents his logical dalil and argues that direction refers to a place, whereas Allah is not directed and placed.

However, these recapitulations do not reinforce each other's statements because the existence of Allah is concealed, and thus, humans are unable to know it except by referring to the 
source of revelation. Ibn Taimiyyah (2000) asserted that the concealed matters in the aqidah are unlikely to be answered without the source of revelation. Furthermore, referring solely to logical dalil without being supported by the revelation dalil will lead to exposure to many offences resulting in consequence of thinking beyond the boundaries of the human minds.

All the informants agree that the Muslim community in Malaysia lacks knowledge of Allah, and their knowledge is mostly based on their observations. To address this problem, the informants suggest solutions through the academic aqidah education system and that it should start from early childhood education, as suggested by Firdaus (2013) and what Apple (2016) has worked on by writing books for children on this issue with authentic Islamic sources and scientific facts.

\section{Conclusion}

Aqidah is mandatory for Muslims to acquire and it is derived from the revelation, particularly from the Qur'an and ahadith. There are many issues of ghaibiyyat (unseen) in the knowledge of aqidah that must be referenced to authentic sources of revelation. Hence, regarding the question of where Allah is, it has been answered in the Qur'an and ahadith. However, when this concealed matter is dealt with by using the mind, weak answers are conjured.

Based on the informants' answers to this issue, it is obvious that the informants' understanding of the whereabouts of Allah and their knowledge of the dalil about it is shallow. Only one informant could answer correctly, while the remaining 13 informants do not know the revelation dalil. Nevertheless, even though one of the informants did answer well, his level of knowledge of its dalil is very weak because his arguments are inaccurate. Therefore, it can be concluded that a majority of the informants fail to answer this question well because they do not know and understand its revelation dalil. The finding is in agreement with the earlier hypothesis that the knowledge of the informants is insubstantial. Hence, it is suggested that a more systematic study of aqidah is instilled among the lecturers in particular and at all levels of the society in general so that they have a good understanding of Allah based on the authentic source of revelation.

This study also has a contribution that is to test the theory that has been established in the current context. It is essential to know the extent of the informants' knowledge of the whereabouts of Allah and their knowledge of the evidence about it. This study also fills the research gap from field research that involves informants consisting of academics wherein the knowledge of researchers, and it has not been found in previous studies.

Notwithstanding the facts, this study has its limitation, whereby the number of informants is small. Although the qualitative method is appropriate for this study and its findings have reached the point of saturation, it is desirable that a quantitative study involving more academicians from diverse academic backgrounds should be undertaken in the future.

\section{Notes}

1. Muhammad bin Ismail Abu 'Abd Allah al-Bukhari, Sahih al-Bukhari (Jiddah: Dar Tauq Al-Najah, 1422H), Chapter Ma Yuhzaru min Zahrah al-Dunya wa al-Tanafus Fiha, no. 6429, vol. 8, p. 91.

2. Muhammad bin Ismail Abu 'Abd Allah al-Bukhari, Sahih al-Bukhari. (Jiddah: Dar Tauq Al-Najah, 1422H), Chapter Ba'th 'Ali bin Abi Talib wa Khalid bin al-Walid ila al-Yaman Qabla Hajjati al-Wada', no. 4351 , vol. 5, p. 163.

3. Abu Al-Husin Muslim bin Al-Hajjaj Al-Qusyairi Al-Naisaburi, Sahih Muslim (Al-Riyad: Dar Al-Taibah, 2006), Chapter Tahrim al-Kalam fi al-Salah wa Naskh ma kana min Ibahitihi, no. 33, vol. 1, p. 381. 
INTERNATIONAL JOURNAL OF ACADEMIC RESEARCH IN BUSINESS AND SOCIAL SCIENCES

Vol. 10, No. 7, July, 2020, E-ISSN: 2222-6990 @ 2020 HRMARS

\section{References}

Abu Zahrah, M. (1996). Tarikh al-Madhahib al-Islamiyyah. al-Qahirah: Dar al-Fikr al-'Arabi.

Al-Asy'ari, A. H. (1397H). Al-Ibanah 'an Usul al-Diyanah. al-Qahirah: Dar al-Ansar.

Al-Asy'ari, A. H. (1413H). Risalah Ila Ahl al-Thaghri bi Bab al-Abwab. al-Su'udiyyah: Jami'ah alIslamiyyah.

Al-Asy'ari, A. H. (1955). al-Luma' fi al-Radd 'ala Ahl al-Ziyagh wa al-Ibda'. al-Qahirah: Matba'ah Mesr Syarikah.

Al-Asy'ari, A. H. (1990). Maqalat al-Islamiyyin. Al-Maktabah al-'Asriyyah.

Al-Asyqar, U. S. (2004). Al-'Aqidah Fillah. 'Amman: Dar al-Nafais.

Al-Bukhari, M. I. (1422H). Sahih Al-Bukhari. Jiddah: Dar Tauq Al-Najah.

Al-Jawzi, I. (1403). Talbis Iblis. Beirut: Dar al-Qalam, 1403H.

Al-Khumais, M. A. (1992). I'tiqad al-Aimmah al-Arba'ah abi Hanifah wa Maliki wa al-Syafi'i wa Ahmad. al-Riyad: Dar al-'Asimah.

Al-Laqqani, B. D. (2004). Syarh Jauharah al-Tauhid. Beirut: Dar al-Kutub al-'Ilmiyyah.

Al-Qaradawi, Y. (2006). Fusul fi al-'Aqidah baina al-Salaf wa al-Khalaf. al-Qahirah: Maktabah Wahbah. Al-Syahrastani, M. A. (1992). al-Milal wa al-Nihal. Beirut: Dar al-Kutub al-'Ilmiyyah.

Alwi, E. A. Z. E. (2007a). Cabaran-cabaran semasa umat islam dan penyelesaiannya menurut agama. Malaysian Journal of Social Administration, 4, 39-57.

Alwi, E. A. Z. E. (2007b). Kajian Ajaran Sesat dalam Pengajian Islam: Satu Sorotan. Jurnal Usuluddin, 26, 1-22.

Al-Zahabi, S. D. (1995). Al-'Uluw li al-'Aliy al-Ghaffar. al-Riyad: Maktab Adwa' al-Salaf.

Apple, E. (2016). Where is Allah? Children's First Questions Series. New Zealand: Books by Emma Apple.

Baadel, S. (2015). Back to Basics: Where Is Allah? -A Survey of Generation Z Youth at the Canadian University of Dubai. International Journal of Social, Education, Economics and Management Engineering, 9(2).

Creswell, J. W. (2008). Educational Research Planning, Conducting and Evaluating Quantitative and Qualitative Research. NJ: Prentice-Hall.

Emroni, A. (2009). Sejarah Pemikiran Tasawuf Falsafi Al-Hallaj. Jurnal Darussalam, 9 (2).

Firdaus, A. (2012). Proses Pendidikan Anak untuk Mengenal Allah. At-Talim, 3.

Glaser, B. G. and Strauss, A. L. (1967). The discovery of grounded theory. Chicago: Aldine.

Haron, A. F. (2008). Allah Antara Tasawwuf Dengan Akidah. Kuala Lumpur: Dewan Bahasa dan Pustaka

Haron, Z., \& Hussin, N. (2013). Islam di Malaysia: Penilaian semula fahaman salafi jihadi dan intepretasi jihad oleh Al Jama'ah Al Islamiyah. Geografia: Malaysian Journal of Society and Space, 9(1), 126-137.

Harras, M. K., al-'Uthaimin, S., and Fauzan, S. (2010). Syarh al-'Aqidah al-Wasitiyyah li Syeikh al-Islam Ibn Taimiyyah. al-Qahirah: Dar Ibn al-Jauzi.

Hatta, M. (2013). Aliran Mu'tazilah dalam Lintasan Sejarah Pemikiran Islam. Ilmu Ushuluddin, 12(1). Ibn Kathir, A. F. (1997). al-Bidayah wa al-Nihayah. Beirut: Dar Ibn Kathir.

Ibn Taimiyyah, T. D. (2000). al-Risalah al-Tadmuriyyah. Al-Riyad: Maktabah al-'Abikan.

Ibrahim, M., Majid, L. A., Awang, J., Kadir, M. N. A., \& Othman, F. M. (2013). Pengajian Islam di IPT Malaysia dalam Menangani Islam Liberal (Islamic Studies in Malaysia IPT in Addressing Liberal Islam). Jurnal Hadhari: An International Journal, 5(1), 37-53. 
INTERNATIONAL JOURNAL OF ACADEMIC RESEARCH IN BUSINESS AND SOCIAL SCIENCES

Vol. 10, No. 7, July, 2020, E-ISSN: 2222-6990 @ 2020 HRMARS

Ismail, A. Z. (1998). Konsep Sifat-sifat Allah: Analisis dan Perbandingan di Antara Aliran Mu'tazilah dan Asya'irah. Jurnal Usuluddin, 8, 67-80.

Jasmi, K. A. (2012). "Metodologi Pengumpulan Data dalam Penyelidikan Kualitatitif." In Proceedings of 2012 Kursus Penyelidikan Kualitatif Siri 1, Melaka, March 28-29, 2012. Johor Bahru: Institut Pendidikan Guru Malaysia Kampus Temenggong Ibrahim.

Kailani, Q. (1991). Fi al Tasawuf al Islam. Cairo: Dar al Ma'arif.

Lincoln, Y. S., and Guba, E. G. (1985). Naturalistic inquiry. Beverly Hills, California: Sage Publications.

Mohamed, S., Jasmi, K. A., \& Zailaini, M. A. (2016). Akhlak Guru dalam Pengajaran dan Pembelajaran Pendidikan Islam (Teacher's Good Behaviour in Teaching and Learning the Islamic Education). Akademika, 86(2).

Muslim, A. H. (2006). Sahih Muslim. Al-Riyad: Dar Al-Taibah.

Patel, I. (2013). Where is Allah: A Commentary and Analysis in Light of the Quran and Sunnah. London: Darussalam International Publications Ltd.

Sahad, M. N. (2007). Pemikiran dan Pemahaman Masyarakat Melayu Kuala Lumpur Terhadap Persoalan Ilahiyyat dalam Akidah Ahl al-Sunah wa al-Jama'ah." PhD diss., Universiti Malaya, Kuala Lumpur.

Salleh, N. M., Tamuri, A. H., \& Amat, S. (2013). Kesahan dan Kebolehpercayaan Instrumen Penghayatan Akidah/Validity and Reliability of the Religious Belief Instrument. International Journal of Islamic Thought, 3, 71.

Salleh, N. M., Tamuri, A. H., Haridi, N. H. M., Amat, S., \& Buang, A. (2017). Kecerdasan emosi bertauhid dalam kalangan remaja Muslim Malaysia (Vitality of the tauhidic emotional intelligence of Malaysia's Muslim adolescents). Geografia-Malaysian Journal of Society and Space, 12(5).

Stewart, A. B. (2016). Where is Allah? Sectarian Debate, Ethnicity, and Transnational Identity among the Salafis of Northwest China. Journal of Islamic and Muslim Studies, 1(1), 12-27.

Nasruddin S. N.F., Johar, S. N., and Embong W. H. (2015). "Gugatan akidah: Benci kepada Islam." In Proccedings of 2015 Seminar Pemantapan Akidah, Dewan Kuliah Khadijah, Fakulti Tamadun Islam, May 16, 2015. Skudai, Johor: Universiti Teknologi Malaysia, 2015.

Wahab, M. R., \& Azmi, M. F. (2013). Kedudukan Akal dalam Pendalilan Akidah. Sains Humanika, 63(1).

Wahab, M. R., \& Omar, S. H. S. (2013). Peringkat Pemikiran Imam al-Ash'ari dalam Akidah/Stages of Imam al-Ash'ari Thought in Theology. International Journal of Islamic Thought, 3, 58.

Wahab, M. R., \& Omar, S. H. S. (2014). Persoalan Mutashābihāt mengenai Istiwā'. Jurnal Usuluddin, 39, 33-70.

Yahaya, A., Hashim, S., Ramli, J., Boon, Y., \& Hamdan, A. R. (2007). Menguasai Penyelidikan Dalam Pendidikan: Teori, Analisis dan Interpretasi Data. Kuala Lumpur: PTS Professional Publishing Sdn. Bhd. 